\title{
Cestovní ruch v soukolí říšské a protektorátní politiky a legislativy. Autonomismus a „demokracie“" za protektorátu: cestovní ruch
}

\author{
Ivan Jakubec
}

Filozofická fakulta, Univerzita Karlova

Kontaktnie-mail:ivan.jakubec@ff.cuni.cz

Tourism within the Contexts of the Reich and Protectorate Politics and Legislation. Autonomism and "Democracy" in the Protectorate: Tourism

\begin{abstract}
:
This paper focuses on the less frequent literary topic of mutual relationship between the Nazi administration and tourism within the Protectorate. The research is based on so far unpublished archive documents (Office of Reich protector, National Archive). This study aims to understand the attitude of the occupation forces (Protectorate and Reich: Correspondence among various Reich offices and towards the Protectorate) while reviewing the research content belonging to the segment of economic-administrative agenda. The planned initiative from the Protectorate to setup a central head office of tourism - "Česko-moravský svaz pro cizinecký ruch" (Der Böhmisch-Mährische Verband für Fremdenverkehr) did not materialize due to the war situation on the fronts, the situation in the Protectorate (the first martial law), and due to the lack of interests of concerned representatives.
\end{abstract}

Keywords:

tourism; Protectorate; Reich; occupation administration; autonomism

Klíčová slova:

cestovní ruch; protektorát; ř́ǐse; okupační správa; autonomie

DOI: $10.14712 / 2464689 X .2018 .22$

Financování: Př́íspěvek vznikl v rámci realizace grantového projektu GAČR č. 16-07164S „Pod dohledem Třetí říše. Cestovní ruch v letech 1939 až 1945“. 
Problematice právních norem platných za protektorátu byla již věnována řada publikací. ${ }^{1}$ Příspěvek je zaměřen na problém vztahu okupační správy k protektorátnímu cestovnímu (cizineckému) ruchu. $Z$ tohoto úhlu pohledu nebyla této problematice dosud věnována dostatečná pozornost v české, ani zahraniční odborné literatuře. ${ }^{2} \mathrm{Z}$ hlediska názvu se na první pohled jedná o oxymóron, nebot' autonomie a demokracie je sice vzájemně slučitelná, avšak v období protektorátu naopak neslučitelná. Studie vychází z nepublikovaných archivních dokumentů (Úřrad ř́šškého protektora, Národní archiv), ve kterých právě toto spojení bylo reflektováno, a učiněná dobová rozhodnutí se o toto pojetí opírala. Samozřejmě, že se nejedná o „glorifikaci“ okupačních rozhodnutí, ale o pochopení postoje okupační moci (protektorát - ř́ŕše, argumentace říšských úřadů mezi sebou a vůči protektorátu) při posuzování uvedené problematiky v jednom ze segmentů hospodářsko-správní agendy. Podívejme se nyní na organizaci cestovního (cizineckého) ruchu ${ }^{3}$ za protektorátu v kontextu vývoje jeho dosavadního řízení.

\section{Organizace cestovního (cizineckého) ruchu v protektorátu}

Cestovní (cizinecký) ruch v protektorátu byl organizován podle německého vzoru. Toto jednoduché a nepochybně správné tvrzení však zcela nevypovídá o dobové, z dnešního hlediska historické realitě (skutečnosti). Porovnejme nejprve ministerskou úroveň řízení a ř́šskou strukturu aplikovanou na protektorát.

Oblast cestovního ruchu od svého formálního „,zaknihování“ nepatřila nikdy pod jeden ústřední úřad či ministerstvo. Historicky patřila oblast cestovního ruchu nejprve pod rakouské ministerstvo veřejných prací a po vzniku Československa pod ministerstvo průmyslu, obchodu a živností jako součást jeho III. sekce. Usnesením vlády ze dne 15 . července 1927 s účinností od 1. září 1927 prostřednictvím presidiálního oběžníku č. 26 (výnos ministra obchodu čj. 5039/pres 1927) došlo k vydělení této oblasti z III. do IV. sekce jako oddělení $\mathrm{F}$ - oddělení pro péči o cizinecký, turistický a kázeňský ruch. ${ }^{4}$

Tato struktura vydržela až do protektorátní reformy. Podle vládního nařízení č. 14/1942 a č. 208/1942 Sb. z. a n. menší část záležitostí cestovního ruchu přešla do nově vytvořeného ministerstva hospodářství a práce (jakéhosi „superministerstva“ pro hospodářství) začleněním ministerstva průmyslu, obchodu a živností, ministerstva veřejných prací a ministerstva sociální a zdravotní správy. Většina oblasti cestovního ruchu přešla pod ministerstvo lidové osvěty. Dalšími ústředními institucemi, které ovlivňovaly cestovní ruch, byly ministerstvo vnitra (vzhledem k silniční dopravě, dále od roku 1942 zahrnující všeobecnou sociální péči a péči o mládež, nároky na dovolenou na zotavenou), ministerstvo železnic, resp. dopravy

1 Např.: MALÝ, K. a kol. Dějiny českého a československého práva do roku 1945. 4., přeprac. vyd. Praha: Leges, 2010; VOJÁČEK, L. - SCHELLE, K. - KNOLL, V. České právní dějiny. 2., upr. vyd. Plzeň: Vydavatelství a nakladatelství Aleš Čeněk, 2010; VOJÁČEK, L. - SCHELLE, K. České právni dějiny do roku 1945. Ostrava: Key Publishing, 2007; Historický vývoj právní úpravy správního řizení a dalšich postupů ve veřejné správě v českých zemích (1918-2005). Olomouc: Právnická fakulta UP Olomouc ve spolupráci s nakl. Periplum a Filozofickou fakultou Univerzity Palackého, 2007.

2 ŠTEMBERK, J. Ústřední svaz pro cizinecký ruch (1940-1948). Cestování včera a dnes, 2006, roč. 3, č. 2, s. 57-62; týž. Ústřední svaz dopravy 1940-1948. Acta Oeconomia Pragensia, 2007, roč. 15, č. 7, s. $405-416$.

3 K výkladu pojmů cestovní, cizinecký ruch srv. ŠTEMBERK, J. Fenomén cestovního ruchu. Pelhřimov: Nová tiskárna ve spolupráci s Vysokou školou obchodní v Praze, 2009.

4 Ministerstvo průmyslu, obchodu a živnosti 1919-1942. Inventář. I. díl. Praha, 1960, s. IX a XI-XII. 
a techniky, ministerstvo zemědělství, později ministerstvo zemědělství a lesnictví (lístkový systém, odběry poukázek pohostinskými zařízeními, platnost protektorátních lístků v Říši a naopak), ministerstvo financí (objem deviz pro zahraniční cesty a cesty z Protektorátu do Ř́iše a naopak), ministerstvo vnitra (nároky na zotavenou ve veřejném sektoru) a v neposlední řadě Nejvyšší úřad cenový. ${ }^{5}$

Vládní nařízení ze dne 23. června 1939 o organické výstavbě hospodářství č. 168/1939 Sb. z. a n. znamenalo do budoucna výraznou změnu. Nařízení se odvolávalo na ústavní zákon zmocňovací z 15. prosince 1938 č. 330/1938 Sb. z. a n. Základ tvořily hospodářské svazy a sdružení svazů, resp. říšské skupiny (Reichsgruppe) dělící se na hospodářské skupiny (Wirtschaftsgruppe) a odborné skupiny (Fachgruppe). Hospodářské svazy zrrizoval, rozpouštěl a slučoval ministr průmyslu, obchodu a živností, stejně tak měnil jejich stanovy a společenské smlouvy a odvolával vedení hospodářských svazů ( $§ 1$ odst. 1 a 2). Na uvedený zmocňovací zákon i vládní nařízení č. 168/1939 Sb. z. a n. se odvolávaly další nařízení a směrnice až do roku 1945.

Ústřední svaz pro cizinecký ruch v Čechách a na Moravě (Zentralverband der Fremdenverkehrswirtschaft für Böhmen und Mähren) vznikl na základě zmíněného vládního nařízení č. 168/1939 Sb. z. a n. a k němu provádějícího nařízení ministra průmyslu, obchodu a živností č. 386/1940 Sb. z. a n. ze dne 9. záŕí 1940. Svaz nuceně sdružoval všechny firmy a podniky zabývající se organizací a činností cestovního ruchu. Nepřekvapí, že sídlem svazu byla Praha. Orgány svazu tvořily předsednictvo, presidiální výbor, užší poradní výbor, zvláštní poradní výbory a valná hromada. Vlastní stanovy měly obě hospodářské skupiny (hostinských živností a skupiny lázní a sportovních míst). ${ }^{6}$ Naplnění vládního nařízení o hospodářské skupině lázní a sportovních míst realizovala vyhláška ministra průmyslu, obchodu a živností č. 184/1941 Sb. z. a n. ze dne 29. dubna 1941, kterou se provádí přihlašovací řízení do hospodářské skupiny lázní a sportovních míst Ústředního svazu pro cizinecký ruch v Čechách a na Moravě. Strukturu Ústředního svazu pro cizinecký ruch v Čechách a na Moravě k 30. červnu 1943 tvořily hospodářské skupiny hostinských živností (2 odborné skupiny s 9 odbory, celkem 35767 členů) a hospodářské skupiny lázní a sportovních míst (3 odborné skupiny s 11 odbory, celkem 742 členů). ${ }^{7}$ Svaz vyvíjel činnost i po druhé světové válce v roce 1948, kdy byl sloučen s Ústředním svazem československé dopravy a Ústředním svazem obchodu.

Ústřední svaz pro cizinecký ruch v Čechách a na Moravě však nesdružoval všechna zařízení v oboru. Podle zmíněného vládního nařízení č. 168/1939 Sb. z. a n. vznikl na základě nařízení ministra průmyslu, obchodu a živností č. 451/1940 Sb. z. a n. ze dne 16. prosince 1940 Ústřední svaz dopravy. Do jeho čtvrté dopravní skupiny ,pomocné živnosti dopravní “ byli zařazeni někteří podnikatelé v cestovním ruchu, jako cestovní kanceláře a podniky, které provozovaly některou z činností cestovních kanceláríi. ${ }^{8}$ Poněkud neorganické začlenění cestovních kanceláří místo do Ústředního svazu pro cizinecký ruch v Čechách a na Moravě nesl tento svaz velmi těžce. ${ }^{9}$

Používána varianta s velkým písmenem na začátku, byt' v dobových pramenech se píše jen s malým písmenem.

6 HAVLÍČKOVÁ, J. Ústřední svaz pro cizinecký ruch ÚSCR 1941-1949. Inventár. Praha, 1975, s. 1.

7 Statistisches Jahrbuch für Protektorat Böhmen und Mähren. Prag: Statistischen Zentralamtes, 1944, s. 359

8 ŠTEMBERK, Ústřední svaz dopravy 1940-1948, s. 405-416.

9 Podrobněji k tomu ŠTEMBERK, Ústřední svaz pro cizinecký ruch (1940-1948), s. 57-62.
} 
Další rovinu, zemskou a regionální, představovaly stejně jako v meziválečném, tak i „válečném“ období nezakázané, ale ani nepodporované tzv. cizinecké svazy zejm. v Praze a v Brně. Jejich vrcholnou organizací bylo přejmenované (Československé) Česko-moravské ústředí cizineckého ruchu. Cizinecké svazy se zaměřovaly na poskytování informačních služeb, propagaci a podíl na koncepčních záměrech rozvoje cestovního ruchu. ${ }^{10}$

Třetí významnou oblastí cestovního ruchu představovaly povolené (,přeregistrované“) spolky, zejména turistické.

\section{Pokus o založení nové centrály: Česko-moravský svaz pro cizinecký ruch}

Kromě legislativně organizačních prací spojených s realizací Ústředního svazu pro cizinecký ruch v Čechách a na Moravě probíhala v podstatě paralelně příprava další centrální organizace spojené s cestovním ruchem. Mimo uvedený Ústřední svaz totiž zůstaly cizinecké svazy a organizace cestovního ruchu z meziválečného období sdružující další svazy. Zatímco organizační výstavba Ústředního svazu se realizovala „shora“ (z říše), souběžná akce k založení nové centrály probíhala „zdola“ (z protektorátu).

Ve fondu Úřadu říšského protektora se nalézá velmi zajímavá složka věnovaná výstavbě „cizinecké organizace“ v protektorátu. ${ }^{11} \mathrm{~V}$ aktové poznámce (Vermerk) z 29. června 1940 se uvádí, že Úřad protektora navštívili sekční rada MUDr. Josef Skokan ${ }^{12}$ (Ministerstvo zdravotnictví), stavební podnikatel Ing. Karel Brauberger ${ }^{13}$ a vrchní odborový rada JUDr. Rudolf Kobosi1 ${ }^{14}$ (Ministerstvo školství a národní osvěty) a předali exposé o návrhu struktury cestovního ruchu v protektorátu. Soustředili se na dva okruhy problémů. Jeden z nich představovala aktivita Českého zemského ústředí obcí, měst a okresů v Praze (Der Böhmische Landeszentralverband der Gemeinden, Städte und Bezirke in Prag) (Škrétova 5) s úmyslem organizovat cizinecký ruch v každé obci podle jednotných směrnic s vrcholným centrálním svazem podle říšského cizineckého svazu (der Deutsche Reichsfremdenverkehrsverband). Navrhovaná cesta vedla přes anketu, ve které by byly dotazovány jednotlivé obce spjaté s cizineckým ruchem. Druhý okruh se týkal akce „Radostí v rodině k síle“ („Kraft durch Freude in der Familie“). Ing. Brauberger byl před dvěma lety v kontaktu s dr. Robertem Leyem, ${ }^{15}$ aby v protektorátu propagoval zmíněnou akci.

10 Z původně 11 členů prvorepublikového Ústředí zbylo v protektorátu jen několik. Kromě pražského cizineckého svazu ještě Klub českých turistů, Svaz hotelierů a velkorestauraterů a Svaz lyžařŭ. ŠTEMBERK, Fenomén cestovního ruchu, s. 28.

11 Národní archiv (NA), fond Úřad říšského protektora (ÚŘP), kart. 1139, čj. IV-1 FV 9554/1940-1941, list $1-2$.

12 MUDr. Josef Skokan (1893-1970). Zdravotnická ročenka Československo, Praha, 1938. Online dostupné dne 24. 4. 2017 na: https://www.uzis.cz/system/files/zdrroc1938_csr.pdf; http://www.prijmeni.cz/Skokan /osobnosti.

13 Ing. Karel Brauberger stavěl spolu s firmou Ing. Frič dálnici v Chřibech. Online dostupné dne 24. 4. 2017 na: http://www.vojna.net/portal/printview.php?t=1724\&start=0.

14 JUDr. Rudolf Kobosil (1874-1946). Online dostupné dne 24. 4. 2017 na: http://www.databazeknih.cz /autori/rudolf-kobosil-79296; BORL, P. Chrámy vědění osiřely: Intervenční úsili predstavitelů protektorátni správy o zmírněni následků německé akce vůči českému vysokému školství na podzim roku 1939. Praha, 2014. Diplomová práce. FF UK. Online dostupné dne 24. 4. 2017 na: https://is.cuni.cz/webapps /zzp/detail/120640.

15 Robert Ley (1890-1945), organizátor Deutsche Arbeitsfront. Stanul před Mezinárodním vojenským tribunálem v Norimberku, kde spáchal sebevraždu. Online dostupné dne 24. 4.2017 na: http://www.historylearning site.co.uk/nazi-germany/nazi-leaders/robert-ley/. 
V této souvislosti plánoval větší zařízení mezi Prahou a Brnem v blízkosti rozestavěné dálnice, nejlépe získat nějaký starý zámek a ten „rozparcelovat“ podle vzoru víkendové chaty (Wochenendhäuser). Tímto návrhem K. Brauberger nezapřel své podnikatelské aktivity ve výstavbě dálnic v protektorátu.

Podle předaného exposé - Přehled o organizaci péče o cestovní ruch (Übersicht über die Organisation der Fremdenfürsorge in Böhmen und Mähren) ${ }^{16}$ - existovalo na území protektorátu pod patronací Česko-moravského ústředí cizineckého ruchu v Praze (Böhmisch-Mährische Fremdenverkehrszentrale in Prag) několik svazů: Cizinecký svaz v Praze, Cizinecký svaz v Brně, Klub českých turistů v Praze, Svaz hotelierů a velkorestauratérů v Praze a Svaz lyžařů v Praze. V ústředí nalezneme zástupce ministerstva průmyslu, obchodu a živností, ministerstva dopravy, ministerstva pro sociální a zdravotní správu a ministerstva veřejných prací. Cizinecký svaz v Praze a v Brně sdružovaly obce, instituce, spolky i jednotlivce s cílem podporovat cestovní ruch v Čechách i na Moravě. Klub českých turistů představoval asi 50000 registrovaných členů organizovaných podle místních skupin a žup s důrazem na domácí cestovní ruch (turistická značení, výstavba turistických ubytoven). Členy Svazu hotelierů a velkorestauratérů byli majitelé větších hotelů, restaurací a kaváren. Svaz lyžařů v Praze podporoval zimní sporty v Čechách i na Moravě. Byl také organizován podle místních skupin a žup.

Na podzim 1940 se uvažovalo o zákonu či vládním nařízení o svazu cestovního ruchu (Fremdenverkehrsverband) v protektorátu. ${ }^{17}$ Podle návrhu měl sloužit k podpoře péče o cestovní ruch včetně lázeňství. ${ }^{18} \mathrm{~V}$ odůvodnění $\mathrm{k}$ návrhu zákona či vládního nařízení o svazu pro cizinecký ruch (Gesetz/Regierungsverordnung über den Fremdenverkehrsverband) se uvádělo, že dosud takové opatření chybí. Dokonce se v prŕípadě cizineckého ruchu hovořilo o „chaotických“ rysech podpory počínaje různými ministerstvy a spolky konče. Jasná a jednotná organizace cizineckého ruchu je předpokladem budoucího zapojení cizineckého ruchu do plnění státněpolitických prostředku a cílů. ${ }^{19}$

Parafovaný dopis Úřadu říšského protektora ze dne 16. září 1940 adresovaný říšskému ministerstvu pro lidovou osvětu a propagandu ${ }^{20}$ konstatoval faktický stav v oblasti cestovního ruchu jako „bezplánovitý a chaotický“ („planlos und chaotisch“). Cizinecký ruch mají na starosti tři ministerstva, dále oblasti, obce a polooficiální svazy cestovního ruchu. V neposlední řadě se o cestovní ruch údajně zajímalo Národní souručenství a Česko-moravské ústředí cizineckého ruchu. Vznikající svaz pro cizinecký ruch Čech a Moravy (Landesfremdenverkehrsverband Böhmen und Mähren) se měl sestávat z pěti svazů: Jižní Čechy, Střední Čechy, Severovýchodní Čechy, Česko-moravská vysočina a Beskydy. Jednalo by se tedy o podobnou strukturu jako v Německu, kde byla v zemi Rakousko (Ostmark) zřízena zemská cizinecká sdružení (Landesfremdenverbände) Vídeň, Dolní

16 NA, ÚŘP, kart. 1139, čj. IV-1 FV 9554/1940-1941, Übersicht über die Organisation der Fremdenfürsorge in Böhmen und Mähren, list 3-5.

17 NA, ÚŘP, kart. 1139, čj. IV-1 FV 9554/1940-1941, list 6-11.

18 NA, ÚŘP, kart. 1139, čj. IV-1 FV 9554/1940-1941, list 6, dopis Ing. J. Charváta Berend Freiherr von Uexhüll, Klánovice 10. záŕí 1940.

19 NA, ÚŘP, kart. 1139, čj. IV-1 FV 9554/1940-1941, Vorwort zum Entwurfe des Geseztes über den Fremdenverkehrsverband, list 11.

20 NA, ÚŘP, k. 1139, čj. IV-1 FV 9554/1940-1941, list 85-87. 
Dunaj/Niederdonau, Štýrsko, Korutany, Horní Dunaj/Oberdonau a Salcburk a Tyroly. ${ }^{21}$ Předpokládalo se, že uvedený zákon vydá ministerstvo obchodu. ${ }^{22}$

Dopis Dr. Hessela z říšského ministerstva lidové osvěty a propagandy adresovaný samotnému protektorovi ze dne 9. ř́ijna 1940 a označený jako „prrísně tajné“ („streng vertraulich“")23 odkazoval na vedoucího německého cizineckého ruchu (míněn pravděpodobně H. Esser), že „,není v německém zájmu centralizovat reklamu [cizineckého ruchu] země a dát jí tím zvýšenou účinnost a hospodárnost"“. ${ }^{24}$ Takové myšlenky je nutné eliminovat a zjistit, proč právě cizinecký ruch v protektorátu vykazuje pevné spojení s německým vzorem. V konceptu odpovědi z 31. října 1941 se sdělovalo, že v případě protektorátu se jedná o zcela jiné podmínky než v ostatních začleněných, resp. obsazených oblastech říše. Protektorát je součást říše a k jeho organickému začlenění do hospodářství a dopravy Velkoněmecka patří také „od nás (tj. Němců) jednotně organizovaný a centrálně řízený cizinecký ruch“. ${ }^{25} \mathrm{~V}$ jiném konceptu odpovědi se ještě uvádělo, že „,bezplánovitá práce“ v oblasti cizineckého ruchu byla označena za neudržitelnou i z české strany. Dále, že ústřední organizace může plnit i politické úkoly jako cílit český cizinecký ruch do říše či naopak jej brzdit. Opakovaly se důvody, že když je hospodářství v protektorátu pod německou kontrolou a řízením, tak to logicky platí i pro cizinecký ruch. ${ }^{26}$ Konečný koncept (z 25. listopadu 1940) byl stručný a poukazoval na jiné poměry v protektorátu než v ostatních začleněných či obsazených oblastech a na řízení a význam hospodářství a tedy i cizineckého ruchu. ${ }^{27}$

K předloze návrhu vládního opatření se zachovala stanoviska některých úřadů německé civilní správy (oberlandráty). Podpora návrhu z jejich strany nebyla jednoznačná. Oberlandrát v Olomouci $\mathrm{k}$ předloze návrhu vládního opatření o Česko-moravském svazu pro cestovní ruch (4. prosince 1940) poukazoval na obavu, že plánované místní spolky by mohly posilovat český tlak na převážně německá města. ${ }^{28}$ Oberlandrát pro okresy středních a severních Čech (6. prosince 1940) návrh schvaloval. ${ }^{29}$ Oberlandrát pro okresy východních Čech (6. prosince 1940) poukazoval, že v návrhu není dostatečně zohledněn německý zájem, resp. německé zastoupení v orgánech svazu. ${ }^{30}$ Pražský oberlandrát (6. prosince

21 Österreichisches Staatsarchiv Wien (ÖStA Wien), fond Archiv der Republik (AdR) 04, kart. 162, sl. 2430/5 Organisation des Fremdenverkehrs in Österreich, Anordnung Nr. 46 des Präsidenten des Reichsfremdenverkehrsverbandes über die Organisation des Landesfremdenverkehrsverbände, Wienerzeitung Nr. 232, 24. 8. 1938, s. 11.

22 NA, ÚŘP, k. 1139, čj. IV-1 FV 9554/1940-1941, Referát Fremdenverkehr adresováno ministerskému radovi dr. Frhr. von Gregory, Prag, 2. 10. 1940, list 29.

23 NA, ÚŘP, k. 1139, čj. IV-1 FV 9554/1940-1941, list. 64.

24 „Es liegt nicht im deutschen Interesse, die Verkehrwerbung des Landes zu zentralisieren und ihr dadurch erhöhte Wirksamkeit und Wirtschaftlichkeit zu geben."Tamtéž.

25 „... ein von uns einheitlich organisierter und zentralgelenkter Fremdenverkehr“. NA, ÚŘP, kart. 1139, čj. IV-1 FV 9554/1940-1941, ř́šský protektor adresováno ministerstvu lidové osvěty a propagandy, Prag, 31. 10. 1940, list 67. NA, ÚŘP, kart. 1139, čj. IV-1 FV 9554/1940-1941, říšský protektor adresováno ministerstvu lidové osvěty a propagandy, Prag, Oktober 1940, list 68-69.

27 NA, ÚŘP, kart. 1139, čj. IV-1 FV 9554/1940-1941, adresováno ministerstvu lidové osvěty a propagandy, Prag, 25. 11. 1940, list 70 .

28 NA, ÚŘP, kart. 1139, čj. IV-1 FV 9554/1940-1941, list 86.

29 Tamtéž, list 87.

30 Tamtéž. 
1940) navrhl doplnit do předpokládané rady vedle zástupce českých zástupců (obecného sportovního výboru, Klubu českých turistů, Svazu lyžařů) také zástupce př́íslušných německých organizací. Pokud by měli být zastoupeni jen zástupci svobodných svazů a nikoliv německých, také lépe bez zastoupení těchto svazů. ${ }^{31}$

Obsahem úředního záznamu (Aktennotiz) o jednání se státním tajemníkem Hermanem Esserem dne 10. ledna 1941 v Mnichově bylo zřízení česko-moravského svazu pro cizinecký ruch. Esser vyjádřil názor, že „není principielně žádoucí“ sjednocení svazů pro cizinecký ruch v protektorátu podle německého vzoru (,prinzipiell nicht erwünscht sei“). „Není úlohou německých úřradů v Protektorátu nějak nehospodářské organizace sjednocovat nebo posilovat, i když se to děje pod německým vedením. Tyto organizace měly by být přenechány sobě podle demokratického [!] principu. Toto je také opakovaně vyslovená vůle vůdce. Proto odmítl zřízení plánovaného česko-moravského svazu pro cizinecký ruch." 32

V polovině ledna 1941 (17. ledna 1941) je datováno Memorandum o řízení cizineckého ruchu v Protektorátu (Memorandum über Regelung des Fremdenverkehrswesens im Protektorat). ${ }^{33}$ Memorandum opakovalo již zmíněnou roztříštěnost v řízení cizineckého ruchu v protektorátu. Uvažovalo o formě korporace veřejného práva pod patronací ministerstva průmyslu, obchodu a živností či organizace bezprostředně podřízené protektorovi nebo čistě německého svazu. Kromě odmítavého stanoviska ministerstva lidové osvěty a propagandy (oddělení pro cizinecký ruch) zprvu odmítlo spolupráci se svazem pro cizinecký ruch stojícím pod dohledem protektorátní vlády. Memorandum se odvolávalo na jednání s H. Esserem dne 10. ledna 1941. Nově v této souvislosti byla zmíněna neochota prostřednicvím německých organizačních metod ,,posilovat Čechy“. Protektorát by se měl, odhlédnuto od hospodářství, ,,spravovat prostřednictvím demokratických metod a zůstat slabý“. 34

Interní dopis Úřadu říšského protektora z 22. února 1941 však poukazoval na posun v postoji říšských orgánů. Podle vyjádření dr. Mahlo (18. února 1941) se dr. H. Esser měl vyjádřit v tom smyslu, že již nemá námitek proti zř́zení ústředního svazu pro cizinecký ruch protektorátní vládou. Prezidenta svazu však musí jmenovat protektor na návrh ministra průmyslu, obchodu a živností. ${ }^{35}$

Vládní rada Dr. Danzmann z Úřadu říšského protektora sděloval ministerskému radovi Dr. Hesselovi v řŕšském ministerstvu lidové osvěty a propagandy z 15. srpna 1941, že zř́izení takového svazu je žádoucí jak z věcného, tak politického hlediska. „Absence

31 Tamtéž, list 89.

32 „Es sei nicht Aufgabe der deutschen Behörden im Protektorat irgendwelche nicht wirtschaftliche Organisationen zusammenfassen oder zu kräftigen, auch wenn es unter deutscher Leitung geschehe. Diese Organisationen sollten nach demokratischem Prinzip sich selbst überlassen bleiben. Dies sei auch der wiederholt ausgesprochene Wille des Führers. Die Errichtung des geplanten böhmisch-mährischen Verbandes für Fremdenverkehr lehne er daher ab.“NA, ÚŘP, kart. 1139, čj. IV-1 FV 9554/1940-1941, Aktennotiz über die Besprechung mit Herrn Staatssekretär Esser am 10. 1. 1941 in München, list 93.

33 NA, ÚŘP, kart. 1139, čj. IV-1 FV 9554/1940-1941, Memorandum über Regelung des Fremdenverkehrswesens im Protektorat, list 94-95.

$34, \ldots$ leht prinzipiell eine auch unter deutscher Führung stehende zusammenfassende Organisation des Fremdenverkehrs ab; es sei nicht Aufgabe der deutschen Behörden, im Protektorat deutsche Organisationsmethoden einzuführen uns dadurch die Tschechen zu stärken; das Land solle, abgesehen von der Wirtschaft, sich durch demokratische Methode regieren und schwach erhalten bleiben." Tamtéž, list 95.

35 NA, ÚŘP, kart. 1139, čj. IV-1 FV 9554/1940-1941, Prag, 22. 2. 1941, list 101. 
takové organizace probouzí na české straně opakovaně úsilí vyplnit mezery výstavbou vlastní organizace pro cizinecký ruch. Přitom zůstává skrytý úmysl pod rouškou podpory cizineckého ruchu provozovat věci, které nemohu být od nás povoleny.“"36 Organizace byla v novém návrhu zjednodušena. Odpadla regionální sdružení (regionale Fremdenverkehrsverbände). Naopak byly včleněny tzv. cizinecké obce (Fremdenverkehrsgemeinden). Odpadly cizinecké spolky (Fremdenverkehrsvereine). Svaz byl podřízen protektorátní vládě. Z ,politických důvodů“ nebylo účelné zrrídit organizaci nařízením protektora, nebot' by byla narušena ,,autonomie“. Předsednictvo na návrh některého z ministerstev jmenuje protektor. Prezident svazu musí být Němec, zástupce může být Čech. ${ }^{37}$

Pozměněný návrh na zřízení česko-moravského svazu pro cizinecký ruch je datován 18. srpna 1941 (Geänderter Entwurf einer Verordnung über die Errichtung des BöhmischMährischen Verbandes für Fremdenverkehr (BMF). ${ }^{38}$ Podle prvního paragrafu byla cílem podpora cizineckého ruchu a lázeňství. V radě měli zasedat zástupci příslušných ministerstev: po jednom zástupci ministerstvo průmyslu, obchodu a živností, ministerstvo vnitra, ministerstvo financí, ministerstvo pro správu sociální a zdraví, ministerstvo dopravy, Ústřední úřad statistický, Česko-moravské ústř̌edí cizineckého ruchu, Ústřední svaz pro cizinecký ruch v Čechách a na Moravě, zástupci stálé delegace samosprávných organizací v Čechách a na Moravě a pět zástupců tzv. obcí cizineckého ruchu (Fremdenverkehrsgemeinde) (§ 5). Návrh předložil vrchní vládní rada dr. Danzmann z Úřadu říšského protektora radovi Dr. Hesselovi z ř́šského ministerstva lidové osvěty a propagandy. Ten odpověděl, že v některých rysech jde proti ř́ŕšskému zákonodárství. Než získá schválení státního tajemníka dr. Essera a ministerského rady dr. Mahlo, navrhl nahradit „sjednocení“ slovem „podpora“. ${ }^{39}$ Další sledování této „kauzy“ neumožňuje stav pramenné základny. Tím není vyloučeno v budoucnu doplnění této bezesporu zajímavé situace v cestovním ruchu v protektorátu, např. prrípadným studiem příslušného říšského ministerstva pro cestovní ruch ministerstva lidové osvěty a propagandy.

\section{Závěr}

Během projednávaného návrhu od června 1940 do srpna 1941 se měnila argumentace Úřadu ř́ršského protektora ve styku s říšskými úřady, resp. ministerstvem lidové osvěty a propagandy, stejně jako forma od návrhu zákona k vládnímu nařízení. Současně je nutné upozornit, že paralelně s přípravou vzniku „standardizovaného“ Ústředního svazu pro cizinecký ruch probíhala jednání o další ústřední organizaci cizineckého ruchu. Jistě to není náhodné. Mohlo v tom hrát roli vymezení kompetencí, tedy podchycení těch uskupení, která nespadala pod vzniklý Ústřední svaz, osobní důvody aj. Pro zodpovězení této otázky bude nutné získat další informace $\mathrm{z}$ archivních dokumentů. Vzhledem k jejich roztř́íštěnosti to bude poněkud složitější.

36 „Das Fehlen einer derartigen Organisation erweckt tschechischerseits immer wieder Bestrebungen, die Lücke durch den Aufbau einer eigenen Fremdenverkehrsorganisation auszufüllen. Dabei besteht die versteckte Absicht, unter dem Deckmantel der Fremdenverkehrsförderung Dinge zu betreiben, die von uns nicht gebilligt werden können.“NA, ÚŘP, kart. 1139, čj. IV-1 FV 9554/1940-1941, list 163.

37 Tamtéž, list 163-164.

38 NA, ÚŘP, kart. 1139, čj. IV-1 FV 9554/1940-1941, Geänderter Entwurf einer Verordnung über die Errichtung des Böhmisch-Mährischen Verbandes für Fremdenverkehr (BMF), list 168-170.

39 Tamtéž, list 174-175. 
Nová centrála Česko-moravský svaz pro cizinecký ruch (Der Böhmisch-Mährische Verband für Fremdenverkehr) tedy nevznikla. Na její „,nevznik“ měla patrně vliv řada faktorů. Mezi nimi jistě hrála roli situace na frontě, nebot' na konci roku 1941 se nedostavil kýžený vojenský úspěch německých zbraní, stejně jako situace v protektorátu (první stanné právo) a malá chut' představitelů zamýšlených subjektů ke spolupráci. Jako jeden z př́kladů uved'me sloučení Klubu českých turistů (KČT) a České obce turistické (ČOT), která se sice formálně realizovala, nikoliv však prakticky. Do Klubu českých turistů vstoupila v roce 1939 Česká obec turistická, ale ,pro nehody v poměrném zastoupení v ústředním výboru se v roce 1940 opět osamostatnila“. 40

Na tomto prríkladu je zřejmý německý ambivalentní postoj k protektorátu a jeho potřebám. Na jedné straně se bral v úvahu hospodářský potenciál protektorátu jako součást Říše, na druhé straně stála snaha minimálně oficiálně podporovat ,autonomii“ protektorátu. Dlouho odmítavý postoj říšskoněmeckých úřadů byl pravděpodobně ovlivněn několika důvody. Mezi ně lze zařadit nedůvěru k návrhu, pocházejícímu z protektorátu, resp. od Čechů, ač byl věcně obtížně napadnutelný; zejména zda návrh něco neskrývá. Dále sem jistě patří překvapivý moment v kontextu právě zahájené světové války, a tedy pro Němce zcela okrajový. Dalšími možnými faktory mohla být demonstrace „,autonomie“, správy protektorátu a zkoumání, zda se tím neposiluje český živel i v rovině organizační na úkor německého $v$ protektorátu, či př́ilišná emancipace $\mathrm{v}$ rámci řízené autonomie. Paradoxně se pro návrh pozitivně vyjadřoval Úřad říšského protektora na rozdíl od říšského ministerstva pro lidovou osvětu a propagandu. Nakonec zvítězila snaha po organizovaném pořádku, mít i oblast cestovního ruchu pod dohledem, ale současně jej zcela nezakázat. Nešlo by to ani z obecného hlediska, protože možnost opuštění svého bydliště na několik hodin či dnů by se mohlo negativně projevit právě v oblasti, o které Němcům nejvíce šlo, o hospodářský výkon a „klid“"v protektorátu.

$40 \quad$ BABIČKA, V. Klub československých turistů 1888-1948. Inventář. Praha, 1977, s. 6; srv. obdobně vylíčený vývoj: HAIN, Z. a kol. Československá obec turistická ČOT. 1928-1948. Inventár. Praha, 1974, s. 5. 


\section{Př́loha}

Návrh vládního nařízení na vznik Česko-moravského svazu pro cestovní ruch

z 18. srpna 1941

Geänderter Entwurf.

einer Verordnung über die Errichtung des Böhmisch-Mährischen

Verbandes für Fremdenverkehr (BMF).

\section{$\S 1$}

1) Zur Förderung des Fremdenverkehrs- und Heilbäderwesen im Protektorat Böhmen un Mähren wird der Böhmisch-Mährischen Verbandes für Fremdenverkehr (BMF) mit dem Sitze in Prag errichtet.

2) Der BMF ist eine Körperschaft öffentlichen Rechts.

$\S 2$

Der BMF hat die Aufgabe, den Fremdenverkehr und das Heilbäderwesen zu fördern und zu pflegen, sowie die den Fremdenverkehr dienenden Maßnahmen und die Fremdenverkehrswerbung einheitlich zusammenfassen und zu leiten.

\section{$\S 3$}

1) Die Organe des BMF sind:

1. Vorstand

2. Der Beirat.

2) Der Vorstand besteht aus einem Präsidenten und einem oder mehreren Stellvertretern.

3) Der Präsident und die Stellvertreter werden vom Minister für Industrie, Handel und Gewerbe ernannt und einberufen.

\section{$\S 4$}

1) Der Präsident oder seiner Stellvertreter vertreten den BMF nach außen.

2) Der Präsident gibt dem BMF eine Satzung, die der Genehmigung des Ministers für Industrie, Handel und Gewerbe bedarf.

3) Der Präsident beruft den Beirat zu Arbeitstagungen, deren Vorsitz er führt.

4) Der Präsident stellt einen jährlichen Wirtschaftsplan und eine Umlageordnung auf und setzt die jährliche Höhe der Umlagen fest, die von den Fremdenverkehrsgemeinden entrichtet werden. Der Wirtschaftsplan, die Umlagsordnung und die Festsetzung der Umlagen bedürfen der Genehmigung des Ministers für Industrie, Handel und Gewerbe, des Ministers der Innern und des Ministers der Finanzen.

\section{$\S 5$}

1) Der Beirat hat die Aufgabe, Maßnahmen zur Förderung und Pflege des Fremdenverkehrs vorzuschlagen und das einheitliche Zusammenwirken aller am Fremdenverkehr beteiligten Behörden, Körperschaften und Vereine im Sinne des BMF zu gewährleisten.

2) Dem Beirat gehören an: je ein Vertreter des

a) Handelsministeriums für Industrie, Handel und Gewerbe

b) Ministeriums der Innern

c) Finanzministeriums 
d) Ministeriums für soziale und Gesundheitsverwaltung

e) Verkehrsministeriums

f) Statistischen Zentralamtes

g) Zerntralverbandes der Fremdenverkehrswirtschaft

h) Zentralverbandes des Verkehrs für Böhmen und Mähren

i) der ständigen Delegation der Selbstverwaltungsorganisationen in Böhmen und Mähren sowie fünf Vertreter

k) der Fremdenverkehrsgemeinden

3) Der Präsident des BMF kann weitere Mitglieder des Beirates ernennen.

$\S 6$

1) Dem BMF gehören als Pflichtmitglieder sämtliche Fremdenverkehrsgemeinden an.

2) Fremdenverkehrsgemeinden sind solche Gemeinden, in denen die Zahl der Fremdenverkehrsübernachtungen im Jahre regelmäßig 1/4 der Einwohnerzahl übersteigt. Gemeinden, die einen erheblichen Ausflugsverkehr haben, können zu Fremdenverkehrsgemeinden bestimmt werden.

3) Das Ministerium für Industrie, Handel und Gewerbe bestimmt auf Antrag des Präsidenten, ob eine Gemeinde Fremdenverkehrsgemeinde ist.

4) Der Präsident kann von Gemeinden, die Auskünfte verlangen, deren er zur Vorbereitung seines Antrages bedarf. Weigert sich eine Gemeinde, die zur Fremdenverkehrsgemeinden bestimmt ist, dem BMF beizutreten, so kann das Ministerium für Industrie, Handel und Gewerbe im Einvernehmen mit dem Innenministerium auf Antrag des Präsidenten den Beitritt an Stelle der Gemeinde erklären.

\section{$\S 7$}

Die Fremdenverkehrsgemeinde entrichtet eine Abgabe an den BMF (§ 4, Punkt 4).

$\S 8$

Der BMF ist von Gebühren für seine Eingaben, Korrenspondenzen mit öffentlichen Körperschaften mit Ausnahme des gerichtlichen Verfahrens befreit, desgleichen für seine Bücher unf Aufzeichnungen, für Rechtsurkunden und Rechtsgeschäfte, die für die Ereichung des Zweckes des BMF erforderlich sind. Das bewegliche Vermögen des BMF ist vom Gebührenaequivalent befreit.

\section{$\S 9$}

Der Minister für Industrie, Handel und Gewerbe kann im Einvernehmen mit den beteiligten anderen Ministerien, Vereinigungen oder Verbänden, die sich mit Fragen des Fremdenverkehrs befassen, auf Vorschlag des Präsidenten des BMF auflösen, zusammenlegen oder ihre Satzungen ändern. Das Vermögen derartig aufgelöster Vereine geht, soweit die Passiven die Aktiven nicht überschreiten, auf den BMF über.

$$
\S 10
$$

Diese Verordnung trit mit dem Tage der Veröffentlichung in Kraft. Sie wird vom Minister für Industrie, Handel und Gewerbe durchgeführt. 